Удк 615.322:547

\title{
ХРОМАТОГРАФИЧЕСКАЯ ХАРАКТЕРИСТИКА ЭКСТРАКТА STELLARIA MEDIA (CARYOPHYLLACEAE)
}

\author{
() А.С. Сухих ${ }^{* 1}$, П.В. Кузнецов ${ }^{1}$, Л.С. Теслов ${ }^{2}$ \\ ${ }^{1}$ Кемеровская государственная медицинская академия Минздрава России, \\ ул. Ворошилова, 22а, Кемерово, 650029 (Россия), e-mail:Suhih_as@list.ru \\ ${ }^{2}$ Санкт-Петербургская химико-фрармацевтическая академия Минздрава \\ России, ул. проф. Попова, 14, Санкт-Петербург, 197022 (Россия)
}

C использованием сефадекса LH-20 и его модифицированного аналога в режиме неклассической аффинной хроматографии проведено разделение на хроматографические фракции, извлечения травы Звездчатки средней. Компонентный состав выделенных фракций проанализирован с использованием ГЖХ-МС и ВЭЖХ. Определены микрокомпоненты, среди которых обнаружено наличие стероидов и некоторых типов алкалоидов производных $\beta$-карболина. Показана возможность применения модифицированного сефадекса LH-20 для препаративного выделения флавоноидов. Впервые установлено наличие в экстракте растения некоторых типов серусодержащих фенилпропаноидов, идентифицирован кемпферол.

Ключевые слова: Звездчатка средняя, азоадсорбенты аффинного типа, сефадекс LH-20, кемпферол, алкалоиды, производные $\beta$-карболина.

\section{Введение}

Представитель рода Stellaria Звездчатка средняя (Stellaria media (L.) Vill.) распространена повсеместно и рассматривается как сорное растение. В последнее время растения рода Stellaria семейства гвоздичных (Caryophyllaceae) привлекают внимание исследователей своими биологическими и фармакологическими свойствами [1-4]. По данным литературы, в состав растения входят: флавоноиды, тритерпеновые сапонины, дубильные вещества, аскорбиновая кислота [5, 6]. В недавнем исследовании [1] определено, что растения рода Звездчатка, произрастающие в Западносибирском регионе, содержат полисахариды, тритерпеновые гликозиды олеаноловой кислоты, кумарины, дубильные вещества, каротиноиды, аскорбиновую кислоту. В отличие от произрастающих в европейской части России образцы, собранные на территории Томской области, Красноярском крае, содержат флавоноиды и фенолкарбоновые кислоты лишь в следовых количествах [1]. В работе [7] приведены данные о содержании в S. media: синаповой кислоты, витаминов С и Е. В то же время в химии природных веществ известно, что использование различных хроматографических сорбентов для выделения основных компонентов из одного и того же природного объекта приводит к отличительным физико-химическим характеристикам конечного целевого продукта [8]. Цель работы сравнительное определение состава хроматографических фракций экстракта Stellaria media полученных с использованием сефадекса LH-20 и его азо-аналога.

Сухих Андрей Сергеевич - старший научный сотрудник центральной научно-исследовательской лаборатории, кандидат фармацевтических наук, доцент, тел.: (3842) 52-18-10, e-mail: suhih_as@list.ru

Кузнеиов Петр Васильевич - заведующий кафедрой фармацевтической химии, доктор фармацевтических наук, профессор, тел.: (3842) 35-89-16

Теслов Леонид Степанович - доцент кафедры фармакогнозии, кандидат фармацевтических наук, тел.: (812) 234-57-29

\footnotetext{
* Автор, с которым следует вести переписку.
}

\section{Экспериментальная часть}

Растение было собрано на территории Топкинского района Кемеровской области, вблизи села Топки во второй половине июля 2010 г. Сырье подвергнуто сушке в тонком слое в затененном, хорошо проветриваемом помещении. Воздушно-сухое сырье в сентябре 
2010 г. трехкратно обрабатывали 70\%-ным этиловым спиртом содержащим 0,01 М гидроксида натрия. Полученные извлечения объединены и подвергнуты хроматографическому анализу. Этиловый спирт 70\%-ный приготовлен из спирта-ректификата ГОСТ 5964-93 по правилам разведения, изложенным в ГФ ХІ издания.

В качестве сорбентов в работе использовались: сефадекс LH-20 (Sephadex® LH-20 (Pharmacia Shweden), и его модифицированный аналог - азоэпоксиадсорбент аффинного типа (азо-ААфТ) синтез которого осуществляли по методике [9]. Наличие оксипропильной перешивки у сефадекса LH-20 определяет характер хроматографического разделения как гель-фильтрационный, адсорбционный и распределительный. Фракции собирали по 1 мл с помощью коллектора (Diafrak, Россия). В качестве элюентов использовали бидистиллированную воду (1 по 30 фракции). С 31 по 87 фракции в качестве элюента использовали 0,01 M NaOH.

Полученные пиковые фракции анализировались в режиме ВЭЖХ и ГЖХ-МС. Для ВЭЖХ применяли хроматографическую систему «Альянс» (Waters), оснащенную детектором с фотодиодной матрицей при длине волны 255 нм. Колонка Atlantys C18 (3,9×150 мм) 5 мкм. Элюирование градиентное с использованием $0,1 \%$ водного раствора ортофосфорной кислоты и ацетонитрила $(78: 22)$. Скорость потока составила 1 мл/мин, объем инжекции - 20 мкл. Температура колонки $-30^{\circ} \mathrm{C}$.

Газожидкостная хроматография с масс-спектрометрической детекцией (ГЖХ-МС) выполнена на приборе Finnigan TraceDSA (США) колонка TR-MS, газ-носитель гелий, скорость потока 5 м/мин. Температуру колонки программировали от 100 до 250 со скоростью $10{ }^{\circ} \mathrm{C} /$ мин.

\section{Обсуждение результатов}

Известно, что метод ГЖХ с масс-спектрометрической детекцией отличается высокой чувствительностью и определенной универсальностью. Эти факторы, в том числе, позволяют использовать метод для анализа извлечений из растительных объектов $[10,11]$. В нашем исследовании, метод ГЖХ-МС использован для анализа хроматографических фракций полученных после разделения экстракта на сефадексе LH-20 и его азоAАфT аналоге. На сефадексе LH-20 в режиме водной элюции были выделены три хроматографические фракции (рис. 1). В Іа фракции методом ГЖХ-МС определены следующие компоненты: лауриновая кислота; 1,5пентандиол; этилнониловый эфир фталевой кислоты; 1,4-циклогександиметамин; этил-15-метилгексадеканоат; $\quad 1,1,3,3,5,5,7,7,9,9,11,11,13,13,15,15$-гексадекаметил-холест-5-ен-3-ол; диизооктилфталат; 3,7,11-триметил-( $E, E)$-трихотек-9-ен-4-ол; $\quad$ 2,4-диметил-бензо- $\gamma$-хинолин; $\quad$ 2,4,6,-циклогептатриен-1-он; $1,1,3,3,5,5,7,7,9,9,11,11,13,13,15,15$-гексадекаметил-2,4,6-циклогептатриен-1-он; декаметилциклотрисилоксан.

Фракция ІІа содержит: миристиновую кислоту; 9-октадиенан; 1,3,5,-триазин-2,4,6,-(1H,3H,5H)трион; 3-фенил-1-бензилиндол; пиридин-3-карбоксамид; декаметилиндолизин; декаметил 1,2,4-триазол-3амин; 1,4-фенилендин-(2,4,6-триметил)циклогептатриен-1-он; $N$-метил-1-адамантанацетамид; 2,4,6,-циклогептатриен-1-он. Фракция имеющая наибольшее удерживание - IIIа, содержит следующие компоненты: 3пропокси- $L$-аланин; 1,2-диэтил-1,2-гидразиндикарбоксальдегид; мочевина; 1-(4,7дигидро-2-метил-7-оксопиразоло)[1,5- $\alpha]$ пиримидин-5-ил.

В полученных после LH-20 и его азо-ААфТ аналога фракциях I и II, методом ГЖХ-МС показано наличие миристиновой и стеариновой кислот. Необходимо отметить, что данные кислоты также обнаружены в черноморской бурой водоросли Colpomenia peregrine[12].

В случае применения модифицированного азо-ААфТ сорбента было выделено четыре хроматографические фракции (рис. 2). При этом выделена фракция IVб, которая получена в режиме элюции 0,01 M $\mathrm{NaOH}$.

По данным ГЖХ-МС компонентной состав первой хроматографической фракции после азо-ААфТ (рис. 2) представлен следующими группами веществ.

Алифатические структуры: Обнаруженные алифатические вещества в выделенных хроматографических фракциях представлены в таблице 1. Можно отметить, что алифатические структуры не обнаружены в первой хроматографической фракции. Тогда как максимальное их количество содержится в IVб хроматографической фракции при элюции раствором $0,01 \mathrm{M} \mathrm{NaOH}$. Это объясняется липофильными свойствами как сорбента, так и удерживаемых веществ. 


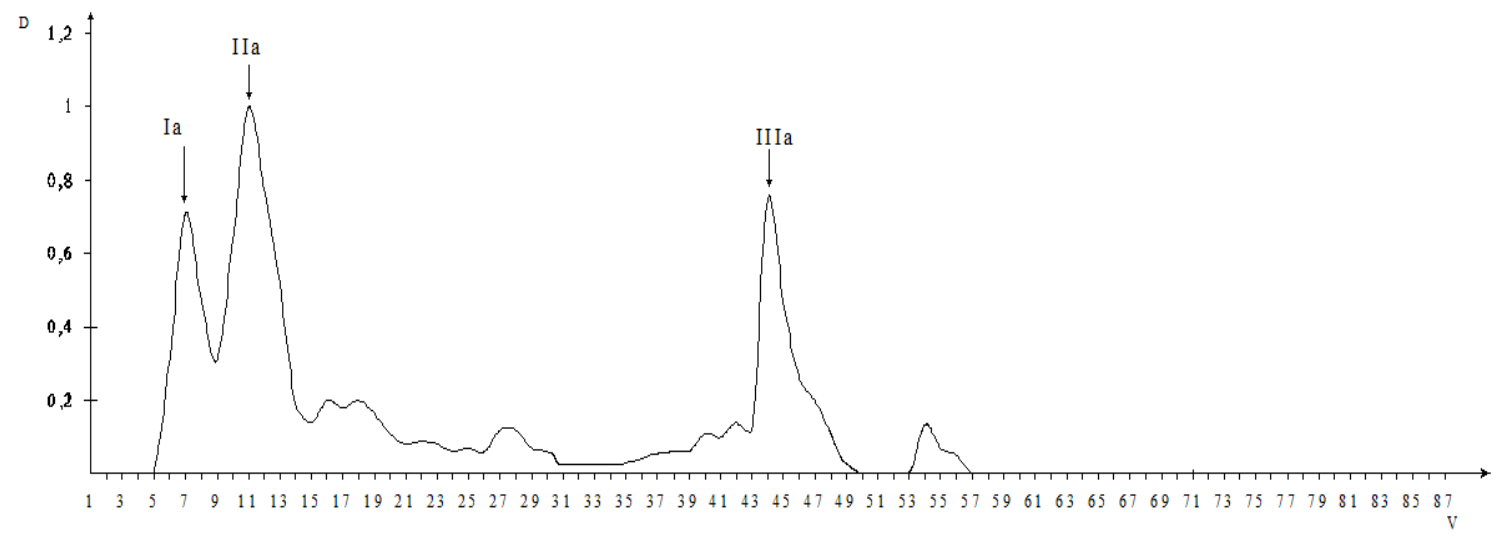

Рис. 1. Хроматограмма извлечения на сефадексе LH-20

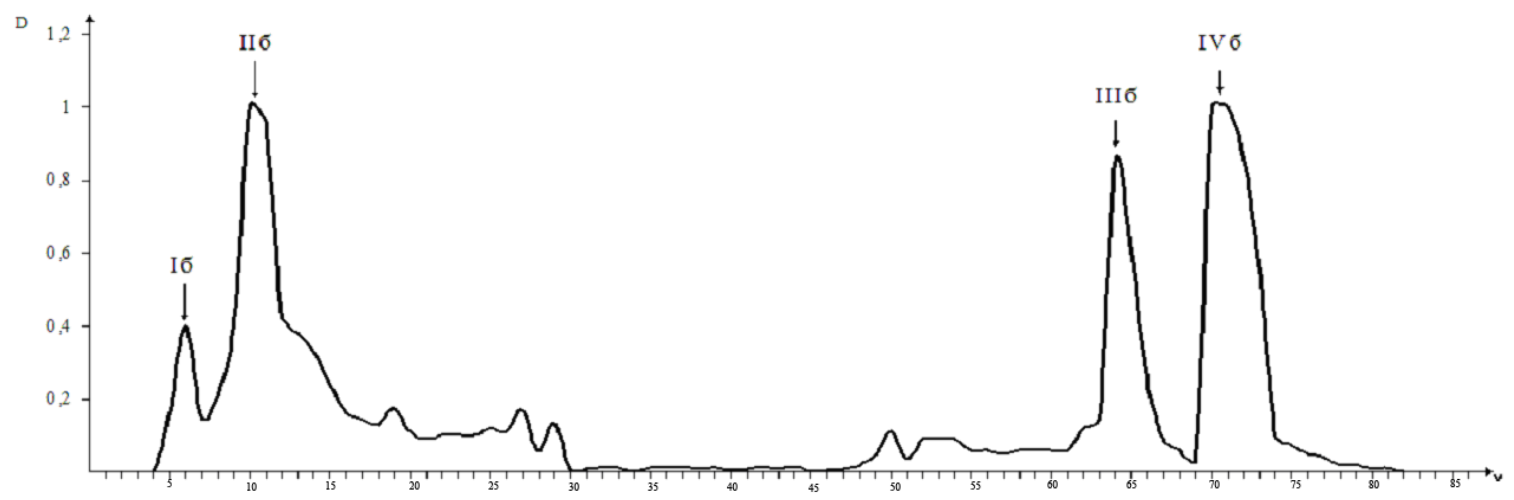

Рис. 2. Хроматограмма извлечения на модифицированном сефадексе LH-20 с иммобилизованными фенольными соединениями из Звездчатки в качестве лиганда [9]

Таблица 1. Алифатические компоненты хроматографических фракций

\begin{tabular}{|c|c|c|c|c|c|}
\hline № & $\begin{array}{c}\text { Фрак- } \\
\text { ция }\end{array}$ & $\begin{array}{l}\text { Время удер- } \\
\text { живания, } \\
\text { мин }\end{array}$ & RSI* & Компонент & Формула \\
\hline 1 & ІІб & 20,12 & 701 & 2-метилгексадекан-1-ол & \\
\hline 2 & ІІб & 22,37 & 740 & 2-гексадеканол & \\
\hline 3 & ІІб & 26,38 & 796 & $\begin{array}{c}\text { этиловый эфир гексадекановой } \\
\text { кислоты }\end{array}$ & \\
\hline 4 & ІІІб & 18,01 & 643 & $\begin{array}{c}\text { метиловый эфир 10,11-эпокси-7-этил- } \\
\text { 3,11-диметил-(E,E)-uңис-2,6- } \\
\text { тридекадиеновой кислоты }\end{array}$ & \\
\hline 5 & ІІІб & 26,36 & 763 & $\begin{array}{c}\text { этиловый эфир гексадекановой } \\
\text { кислоты }\end{array}$ & \\
\hline 6 & IVб & 15,52 & 671 & 3,7,11-триметил-1-додеканол & \\
\hline 7 & ІVб & 17,88 & 756 & 2,6,10-триметилтетрадекан & \\
\hline 8 & IVб & 18,90 & 727 & 3,7,11-триметил-1-додеканол & \\
\hline 9 & IVб & 19,33 & 705 & 2-метил-1-гексадеканол & \\
\hline 10 & IVб & 20,17 & 746 & 2-гексадеканол & \\
\hline 11 & IVб & 24,00 & 717 & 9,12,15-октадекатриеновая кислота & \\
\hline
\end{tabular}

*см. работу [10]. 
Ароматические соединения: В хроматографической фракции Іб были определены три производных фталевой кислоты (табл. 2). Вторая фракция (IІб) содержит следующие фталаты: бутилтетрадециловый эфир фталевой кислоты; этилпентадециловый эфир фталевой кислоты, диизооктиловый эфир фталевой кислоты. Фракция ІІІб этилпентадециловый эфир фталевой кислоты; бутилизогексиловый эфир фталевой кислоты; этил 2-пентиловый эфир фталевой кислоты; моно-(2-этил)-гексиловый эфир фталевой кислоты.

Производные фталевой кислоты с различной структурой алкильного остатка определяются в растениях семейства Apiaceae, Caprifoliaceae, Lamiaceae, Amaranthaceae [6, 13, 14]. Известен мощный эффект фталатов как неионогенных ПАВ, этот фактор может обусловливать устойчивость $S$. media к поражению различного типа микромицетов [3].

В ІІІб фракции обнаружен 2,6-диизопропилнафталин - вещество, которое по аналогии с известными антимикотическими препаратами тербинафин и хинофунгин (нафтильный фрагмент в структуре) способно проявлять противогрибковые свойства.

Содержащиеся в IIIб фракции: N,N’-дибензоилоксигександиамин и Z-фенилметиловый эфир 9-октадекановой кислоты можно рассматривать как производные бензойной кислоты. Интересно, что IIб фракция содержит $N, N$-диметил- $S$-1,3-дифенил-2-бутеновый эфир тиокарбоновой кислоты, который способен проявлять антиоксидантные свойства.

В таблице 3 обобщены данные по обнаруженным стероидным соединениям, их аналогам и другим

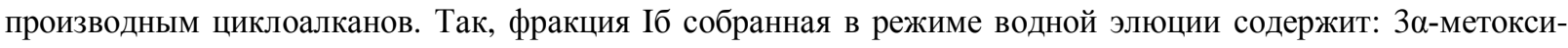
$18[N$-метил- $N$-(2'14эпоксиэтил)амино]-3,9-эпоксипрегнан-11 $\beta, 20$-диол. Относительно многокомпонентной оказалась фракция IIб, в которой определены: 7-оксо-циклобута[ $\alpha]$ дибензо[c,f]циклогептадиен; 9, 10секохолеста-5,7,10-триен-3,24,25-триол или 24,25-дигидроксихолекальциферол и [2-(5-гидроксипентил-2-

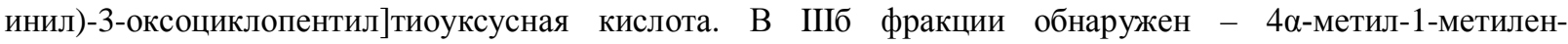
$1,2,3,4,4 \alpha 9,10,10 \alpha$-октагидрофенантрен.

Таблица 2. Ароматические компоненты хроматографических фракций

\begin{tabular}{|c|c|c|c|c|c|}
\hline № & $\begin{array}{c}\text { Фрак- } \\
\text { ция }\end{array}$ & $\begin{array}{c}\text { Время } \\
\text { удерживания } \\
\text { мин }\end{array}$ & RSI* & Компонент & Формула \\
\hline 1 & 2 & 3 & 4 & 5 & 6 \\
\hline 1 & Іб & 25,88 & 856 & изобутилоктадицилфталат & \\
\hline 2 & Іб & 28,19 & 935 & этил 2-пентилфталат & \\
\hline 3 & Іб & 35,80 & 893 & моно(2-этилгексил) фталат & \\
\hline 4 & ІІб & 25,88 & 828 & бутилтетрадицилфталат & \\
\hline 5 & ІІб & 28,19 & 852 & этилпентадицилфталат & \\
\hline 6 & ІІб & 35,80 & 887 & диизооктилфталат & \\
\hline 7 & ІІб & 36,10 и 39,76 & $\begin{array}{l}767 \\
738\end{array}$ & $\begin{array}{c}N, N \text {-диметил- } S-1,3 \text {-дифенил-2- } \\
\text { бутеновый эфир тиокарбоновой } \\
\text { кислоты }\end{array}$ & \\
\hline
\end{tabular}


Окончание таблицы 2

\begin{tabular}{|c|c|c|c|c|c|}
\hline 1 & 2 & 3 & 4 & 5 & 6 \\
\hline 8 & ІІІб & 6,62 & 771 & $N, N^{\prime}$-дибензоилоксигександиамин & \\
\hline 9 & ІІІб & 9,38 & 696 & $\begin{array}{c}\text { фенилметиловый эфир Z-9- } \\
\text { октадекановой кислоты }\end{array}$ & \\
\hline 10 & ІІІб & 20,95 & 849 & 2,6-диизопропилнафталин & \\
\hline 11 & ІІІб & 22,20 & 779 & этилпентадицилфталат & \\
\hline 12 & ІІІб & 25,90 & 898 & бутилизогексилфталат & \\
\hline 13 & ІІІб & 35,80 & 911 & моно(2-этил)гексилфталат & \\
\hline
\end{tabular}

Таблица 3. Производные циклоалканов, стероидные соединения и их аналоги содержащиеся в хроматографических фракциях

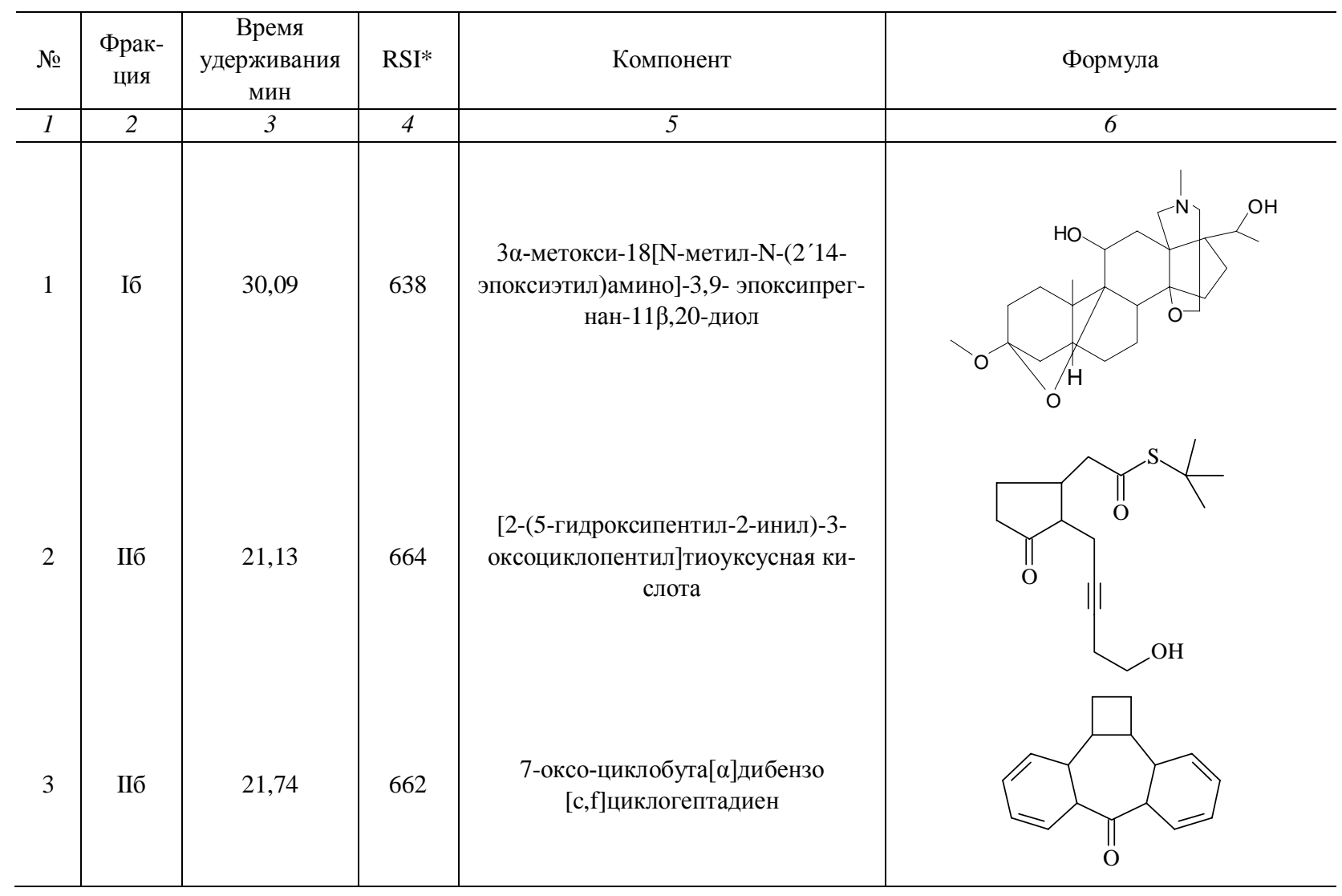


Окончание таблиць 3

\begin{tabular}{|c|c|c|c|c|c|}
\hline 1 & 2 & 3 & 4 & 5 & 6 \\
\hline 4 & ІІб & 30,10 & 688 & $\begin{array}{c}\text { 9,10-секохолеста-5,7,10(19)-триен- } \\
\text { 3,24,25-триол }\end{array}$ & \\
\hline 5 & ІІІб & 19,91 & 663 & $\begin{array}{c}4 \alpha \text {-метил-1-митилен- } \\
1,2,3,4,4 \alpha 9,10,10 \alpha- \\
\text { октагидрофенантрен }\end{array}$ & \\
\hline
\end{tabular}

Соединения, содержащие гетероцикл и их аналоги определены в II III и IV фракциях (табл. 4). Найдено, что фракция ІІб содержит $L$-аскорбиновую кислоту, птерин-6-карбоновую кислоту и 4-метокси6метил-5-нитроизобензофуран-1,3-дион. Особый интерес вызывает наличие содержащегося в IIIб фракции 1-ацетил-20 $\alpha$-гидрокси-16-метиленстрихнана и 2,7-дифенил-1,6-диоксопиридазино[4,5:2',3']пирроло[4,5d]пиридазина обнаруженного в IVб фракции. По нашему мнению, структурные и количественные особенности алкалоидов, содержащихся в Stellaria, требует дополнительных исследований. Интересно отметить, что произрастающая в Европе осока парвская (Carex bnevicollis ) также продуцирует несколько алкалоидов производных $\beta$-карболина. Среди прочих бревиколлин и бревикарин [15]. В работе [2], посвященной изучению S. dichotomata, впервые были выделены и описаны содержащиеся алкалоиды типа дихотомина I.

Достоверность результатов, полученных методом ГЖХ-МС, может находится в достаточно широком интервале. Поэтому данные ГЖХ-МС по обнаруженным компонентам растения должны быть обязательно доказаны в дальнейшем, комплексом физико-химических методов в условиях препаративного накопления.

По данным ВЭЖХ, в этой фракции (IVб) содержится флавоноид, идентифицированный нами (по спектральным характеристикам и методом добавок) как кемпферол. Необходимо отметить, что применение азо-ААфТ позволяет осуществлять также и препаративное накопление флавоноидов. Подобные свойства азо-ААфТ были описаны ранее и использованы для определения примеси флавоноидов в препаратах кумаринов $[16,17]$.

Таблица 4. Компоненты хроматографических фракций, содержащие в структуре гетероцикл

\begin{tabular}{|c|c|c|c|c|c|}
\hline № & Фракция & $\begin{array}{c}\text { Время } \\
\text { удержива- } \\
\text { ния, мин. }\end{array}$ & $\mathrm{RSI}^{*}$ & Компонент & Формула \\
\hline 1 & ІІб & 18,03 & 744 & птерин-6-карбоновая кислота & \\
\hline 2 & ІІб & 34,63 & 670 & $\begin{array}{c}\text { 4-метокси-6-метил-5-нитро- } \\
\text { изобензофуран-1,3-дион }\end{array}$ & \\
\hline 3 & ІІІб & 22,35 & 559 & 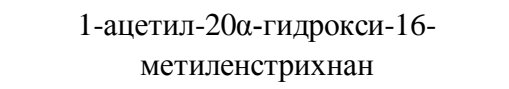 & \\
\hline 4 & IVб & 5,50 & 581 & $\begin{array}{l}\text { 2,7-дифенил-1,6-диоксопиридазино- } \\
\text { [4,5:2',3']-пирроло[4,5-d]-пиридазин }\end{array}$ & \\
\hline
\end{tabular}

\section{Bblвodbl}

Применение сефадекса LH-20 и его модифицированного аналога - азоэпоксиадсорбента аффинного типа позволяют выделить фракции, различающиеся по компонентному составу. В изученных хроматогра- 
фических фракциях показано наличие производных фталевой кислоты. Использованный модифицированный сорбент LH-20 в режиме неклассической аффинной хроматографии проявляет селективность при сорбции флавоноидов. Методом ВЭЖХ в хроматографической фракции IVб после азо-ААфТ сорбента определено наличие кемпферола. С применением ГЖХ-МС впервые установлены азотсодержащие и серосодержащие компоненты Stellaria media, в том числе алкалоиды производные $\beta$-карболина и $N, N$-диметил-S1,3дифенил-2-бутенового эфира тиокарбоновой кислоты.

\section{Список литературы}

1. Горина Я.В. Фармакогностическое исследование некоторых видов рода Stellaria и возможность их использования в медицинской практике: автореф. ... канд. фарм. наук. Пермь, 2012. 25 с.

2. Morikawa T., Sun B., Matsuda H. Wu L.J., Harima S., Yoshikawa M. Bioactive constituents from Chinese natural medicines. XIV. 1) New glycosides of b-carboline-type alkaloid, neolignan, and phenylpropanoid from Stellaria dichotoma L. var. lanceolata and their antiallergic activities // Chem. Pharm. Bull. 2004. Vol. 52, N 10. Pp. 11941199.

3. Шакуров P.P. Антимикробные пептиды сорного растения Stellaria media и их гены: экспрессия и устойчивость к фитопатогенным грибам: автореф. ... к.б.н. Москва, 2011. 24 с.

4. Vanhaecke M., Ende W., Laere A., Herdewijn P. Lescrinier E. Complete NMR characterization of lychnose from Stellaria media (L.) Vill. // Carbohydrate Research. 2006. Vol. 341. Pp. 2744-2750.

5. Энциклопедический словарь лекарственных растений и продуктов животного происхождения / под ред. Г.П. Яковлева, К.Ф. Блиновой. СПб., 1999. 407 с.

6. Растительные ресурсы России: Дикорастущие цветковые растения, их компонентный состав и биологическая активность. / отв. ред. А.Л. Буданцев. Т. 1. СПб., 2008. С. 110-112.

7. Телятьев В.В. Полезные растения центральной Сибири. Иркутск, 1985. $384 \mathrm{c.}$

8. Peuravuori J., Monteiro A., Eglite L., Pihlaja K. Comparative study for separation of aquatic humic-type organic constituents by DAX-8, PVP and DEAE sorbing solids and tangential ultrafiltration: elemental composition, sizeexclusion chromatography, UV-vis and FT-IR // Talanta. 2005. Vol. 65. Pp. 408-422.

9. Сухих А.С., Коршунов А.В., Кузнецов П.В. Синтез эпоксиазоадсорбента аффинного типа для выделения и очистки биологически активных веществ звездчатки средней (Stellaria media (L.)) // Разработка, исследование и маркетинг новой фармацевтической продукции. Т. 63. 2008. С. 339-341.

10. Пушкарева Е.С., Ефремов А.А. Компонентный состав эфирнрого масла полыни холодной (Artemisia frigida) Красноярского края и его отдельных фракций // Сорбционные и хроматографические процессы. 2012. Т. 12, вып. 4. С. 619-623.

11. Sabale A. B., Mane A. A. Chemical investigation of Iphigenia stellata Blatter by GC-MS // Биоорганическая химия. 2012. T. 38. № 3. C. 370-373.

12. Усов А.И., Смирнова Г.П., Каменаская 3., Дмитрова-Конаклиева С.Т., Стефанов К.Л., Попов С.С. Полярные компоненты черноморской бурой водоросли Colpomenia peregrina (Sauv.) // Биоорганическая химия. 2004. T. 30, № 2. C. 182-189.

13. Beck J.J., Shen-Chieh C. The structural diversity of phthalides from the Apiaceae // J. Natur. Prod. 2007. N 5. Pp. 891-900.

14. Растительные ресурсы России: Дикорастущие цветковые растения, их компонентный состав и биологическая активность. Семейства Caprifoliaceae - Lobeliaceae / отв. ред. А.Л. Буданцев. Т. 4. СПб.; М., 2011. 630 с.

15. Семенов А.А. Очерк химии природных соединений. Новосибирск, 2000. 664 с.

16. А.с. № 1770897 (СССР). Способ разделения и выделения кумаринов / П.В. Кузнецов, В.В. Шкаренда. 1992.

17. Шкаренда В.В. Исследование адсорбентов аффинного типа для разделения, очистки и анализа кумаринов и их производных и кумаринсодержащих лекарственных средств: автореф. ... канд. фарм. наук, СПб, 1992. 24 с. 
Sukhikh A.S. ${ }^{*^{*}}$, Kuznetsov P.V. ${ }^{1}$, Teslov L.S. ${ }^{2}$ THE CHROMATHOGRAPHY CHARACTERISTIC EXTRACT STELLARIA MEDIA (CARYOPHYLLACEAE)

${ }^{I}$ Kemerovo State Medical Academy, Russian Ministry of Health, st. Voroshilov, 22a, Kemerovo, 650029 (Russia)

e-mail: Suhih_as@list.ru

${ }^{2}$ Saint-Petersburg Chemical-Pharmaceutical Academy of Ministry of Health of Russia, ul. prof. Popov, 14,

St. Petersburg, 197022 (Russia)

Research of components of extract of a grass of Stellaria is carried out. Sphadex LH-20 and its changed analog in way NAFC division on parts of chromatographyc that are analysed with HPLC and GLC-MS use. It show that use of modified sephadex LH-20, is possible flavonoids preparation distributions. In research, the maintenance of some types alkaloid derivatives is revealed $\beta$-carbolins. For the first time presence at extract of a plant of cempferol is established.

Keywords: Stellaria media, epoxyazoadsorbent affinity type, sephadex LH-20, cempferol, alkaloid derivatives $\beta$ carbolins type.

\section{References}

1. Gorina Ja.V. Farmakognosticheskoe issledovanie nekotoryh vidov roda Stellaria i vozmozhnost' ih ispol'zo-vanija v medicinskoj praktike. Diss. kand. farm. nauk. [Farmakognostichesky study of some species of the genus Stellaria and the possibility of their use in medical practice. Candidate of Pharmaceutical Sciences diss.]. Perm', 2012, 25 p. (in Russ.).

2. Morikawa T., Sun B., Matsuda H. Wu L.J., Harima S., Yoshikawa M. Chem. Pharm. Bull, 2004, vol. 52, no. 10, pp. 1194-1199.

3. Shakurov R.R. Antimikrobnye peptidy sornogo rastenija Stellaria media $i$ ih geny: jekspressija $i$ ustojchi-vost' $k$ fitopatogennym gribam. Diss. kand. bio. nauk. [Antimicrobial peptides weed Stellaria media and their genes: expression and resistance to phytopathogenic fungi. Candidate of Biological Sciences diss.]. Moskva, 2011, 24 p. (in Russ.).

4. Vanhaecke M., Ende W., Laere A., Herdewijn P., Lescrinier E. Carbohydrate Research, 2006, vol. 341, pp. 2744-2750.

5. Jenciklopedicheskij slovar' lekarstvennyh rastenij i produktov zhivotnogo proishozhdenija. [Encyclopedic Dictionary of medicinal plants and animal products]. Ed. G.P. Jakovlev, K.F. Blinova. Sankt-Peterburg, 1999, 407 p. (in Russ.).

6. Rastitel'nye resursy Rossii: Dikorastushhie cvetkovye rastenija, ih komponentnyj sostav i biologicheskaja aktivnost'. [Plant Resources of Russia: Wild flowering plants, their composition and biological activity]. Ed. A.L. Budancev. vol. 1, Sankt-Peterburg; Moscow, 2008, pp. 110-112. (in Russ.).

7. Teljat'ev V.V. Poleznye rastenija central'noj Sibiri. [Useful plants of central Siberia]. Irkutsk, 1985, 384 p. (in Russ.).

8. Peuravuori J., Monteiro A., Eglite L., Pihlaja K. Talanta, 2005, vol. 65, pp. 408-422.

9. Suhih A.S., Korshunov A.V., Kuznecov P.V. Razrabotka, issledovanie i marketing novoj farmacevticheskoj produkcii. [Development, research and marketing of new pharmaceutical products]. 2008, vol. 63, pp. 339-341. (in Russ.).

10. Pushkareva E.S., Efremov A.A. Sorbcionnye i hromatograficheskie processy, 2012, vol. 12, no. 4, pp. 619-623. (in Russ.).

11. Sabale A. B., Mane A. A. Bioorganicheskaja himija, 2012, vol. 38, no. 3, pp. 370-373. (in Russ.).

12. Usov A.I., Smirnova G.P., Kamenaskaja Z., Dmitrova-Konaklieva S.T., Stefanov K.L., Popov S.S. Bioorganicheskaja himija, 2004, vol. 30, no. 2, pp. 182-189. (in Russ.).

13. Beck J.J., Shen-Chieh C. J. Natur. Prod, 2007, no. 5, pp. 891-900.

14. Rastitel'nye resursy Rossii: Dikorastushhie cvetkovye rastenija, ih komponentnyj sostav i biologicheskaja aktivnost'. Semejstva Caprifoliaceae - Lobeliaceae. [Plant Resources of Russia: Wild flowering plants, their composition and biological activity. Family Caprifoliaceae-Lobeliaceae]. Ed. A.L. Budancev. vol. 4, St. Petersburg; Moscow, 2011, 630 p. (in Russ.).

15. Semenov A.A. Ocherk himii prirodnyh soedinenij. [Sketch of Chemistry of Natural Compounds]. Novosibirsk, 2000. $664 \mathrm{p}$.

16. Patent 1770897 (USSR). 1992. (in Russ.).

17. Shkarenda V.V. Issledovanie adsorbentov affinnogo tipa dlja razdelenija, ochistki $i$ analiza kumarinov $i$ ih proizvodnyh i kumarin soderzhashhih lekarstvennyh sredstv: Diss. kand. farm. nauk. [Investigation of such adsorbents for affinity separation, purification and analysis of coumarins and coumarin derivatives and drugs containing. Candidate of Pharmaceutical Sciences diss.], St. Petersburg, 1992, 24 p. (in Russ.).

\footnotetext{
* Corresponding author.
} 